This is the final peer-reviewed accepted manuscript of:

Buonanno, P., Prarolo, G., \& Vanin, P. (2016). Organized crime and electoral outcomes. Evidence from Sicily at the turn of the XXI century. European Journal of Political Economy, 41, 61-74.

The final published version is available online at:

https://doi.org/10.1016/j.ejpoleco.2015.11.002

Rights / License:

The terms and conditions for the reuse of this version of the manuscript are specified in the publishing policy. For all terms of use and more information see the publisher's website. 


\title{
Organized Crime and Electoral Outcomes. Evidence from Sicily at the Turn of the XXI Century
}

\author{
Paolo Buonanno*, Giovanni Prarolo (corresponding author) ${ }^{\dagger}, \quad$ Paolo Vanin ${ }^{\ddagger}$
}

November 4, 2015

\begin{abstract}
This paper investigates the relationship between Sicilian mafia and politics by focusing on municipality-level results of national political elections. It exploits the fact that in the early 1990s the Italian party system collapsed, new parties emerged and mafia families had to look for new political allies. It presents evidence, based on disaggregated data from the Italian region of Sicily, that between 1994 and 2013 Silvio Berlusconi's party, Forza Italia, obtained higher vote shares at national elections in municipalities plagued by mafia. The result is robust to the use of different measures of mafia presence, both contemporary and historical, to the inclusion of different sets of controls and to spatial analysis. Instrumenting mafia's presence by determinants of its early diffusion in the late XIX century suggests that the correlation reflects a causal link.
\end{abstract}

Keywords: Elections, Mafia-type Organizations

JEL codes: D72, H11

\footnotetext{
*Department of Economics, University of Bergamo, Via dei Caniana 2, 24127 Bergamo, Italy. Phone: +390352052681. Email: paolo.buonanno@unibg.it.

${ }^{\dagger}$ Department of Economics, University of Bologna, Piazza Scaravilli 2, 40126 Bologna, Italy. Phone: +390512098873. E-mail: giovanni.prarolo@unibo.it

${ }^{\ddagger}$ Department of Economics, University of Bologna, Piazza Scaravilli 2, 40126 Bologna, Italy. Phone: +390512098120. E-mail: paolo.vanin@unibo.it
} 


\section{Introduction}

The relationship between mafia and politics is a crucial but empirically under-investigated issue. In this paper we explore the connection between mafia presence and party vote shares at national political elections, employing municipality level data from the mafia-plagued Italian region of Sicily.

There is evidence that mafia activities exert a negative effect on development. For instance, for the case of Italy, Pinotti (2015) finds that organized crime is responsible for a $16 \%$ loss in GDP per capita over a 30 year period, Daniele and Geys (2015) show that mafia infiltration reduces the quality of local politicians (measured by their average education level), Barone and Narciso (2014) document mafia's ability to divert a substantial amount of public funds assigned to poor areas, and Daniele and Marani (2011) find that mafia presence is associated to lower FDI. A majority of voters might then in principle support a successful fight against the mafia, if this is not too costly. Yet mafia's persistence (documented for the Italian case, among others, by Buonanno et al., 2015), suggests that either at some point further fighting organized crime has higher social costs than benefits, or that, even when the reverse is true, something in the political process prevents the majority that would benefit from a sharp fight against the mafia from giving rise to effective policies in such direction.

One possible reason, which is in line with theoretical results as well as with anecdotal, judicial and empirical evidence, is that mafia organizations distort electoral outcomes by intervening in the market for votes. As emphasized by Gambetta (1993), transactions in such market are typically illegal, so mafia-type organizations may step in, collect votes (through either threats or rewards to citizens) and supply them to politicians in exchange for favors, with the latter ranging from diversion of public funds and procurement contracts to favorable legislation and lenient prosecution.

The political economic literature has considered vote buying from different perspectives, ranging from an individualized market for votes (Piketty, 1999, 2000; Dekel et al., 2008) to bribes (Snyder, 1991) and to campaign contributions by lobbies (Grossman and Helpman, 1996), but these studies are only indirectly related to mafia's intervention in the market for votes. More directly related are contributions that look at how interest groups condition politicians' choices and, most importantly, how they control citizens' votes. Esteban and Ray (2006) notice that lobbies' willingness to pay to influence politicians depends both on the relevance of their interests and on their wealth. From this point of view, mafia's wealth may render it politically influential even when its interests are socially harmful. Baland and Robinson (2008) develop a model in which landlords control their workers' vote and show that before the introduction of the secret ballot in Chile, right-wing parties representing the interests of landed aristocracy received more votes where patron-client relationships were stronger. Their model may be use- 
ful in the present context because one of the ways in which the mafia controls votes is through patron-client relationships, which are particularly strong in areas in which it exercises an almost monopsonistic role in the labor market, thus being an employer to which citizens have only few and costly alternatives. Acemoglu et al. (2013) propose a model in which non-state armed actors bring votes to politicians, who therefore have a lower incentive to fight them. They also provide empirical evidence on the influence of paramilitaries on elections in Colombia, which is relevant here because violence or its threat is yet another way in which mafia controls votes and thereby buy active support or at least tolerance by politicians.

Most closely related to the present investigation is De Feo and De Luca (2013), who formalize a probabilistic voting model in which mafia sells votes to the party that has more core supporters and is thus expected to win. The reason is that such party needs to offer less public goods to convince swing voters and is thus able to retain higher rents from being in office, so its willingness to pay for votes is higher. They also show empirical evidence from Sicily, according to which after 1970 the Christian Democrats (the majority party until 1992) obtained more votes in Sicilian municipalities plagued by mafia. Their findings are in accordance with judicial evidence of organic relationships between the Sicilian Mafia and several Italian politicians. To pick up just two prominent examples from the Christian Democrats, Vito Ciancimino, mayor of Palermo (Sicily's capital city) in the early 1970s, was later sentenced to eight years of prison for mafia association, and Giulio Andreotti, several times Prime Minister of Italy, was not convicted due to prescription, but according to the court maintained stable relationships with the mafia until 1980.

Documenting empirically mafia's intervention in the market for votes is difficult, as the involved transactions are obviously hidden. We exploit the reshuffling that took place in Italian politics in the early 1990s, which set the stage for a potential search for a new partnership between organized crime and political actors. ${ }^{1}$ The mid 1990s witnessed the emergence of new political leaders and of new mafia lords, who had to find a new balance between fighting each other and collaborating with each other. The most important of the new political leaders, Silvio Berlusconi, founded his Forza Italia party in 1993 and became Italy's prime minister in 1994. Forza Italia and the center-right coalition always won a majority at political elections in Sicily between 1994 and 2013. ${ }^{2}$ Berlusconi's connections with the mafia were often discussed by the

\footnotetext{
${ }^{1}$ Due to widespread corruption scandals and to changes in international affairs, in the early 1990 s the Italian political landscape experienced an earthquake. All major parties, including the Christian Democrats, disappeared, broke down into several minor parties or changed name. At the same time, mafia's fight against its enemies inside the state reached its peak of violence with the assassination in 1992 of two judges, Giovanni Falcone and Paolo Borsellino, who had been responsible for a maxi-trial against the mafia in the late 1980s. In response to such assassinations, many major mafia lords were captured and sentenced.

${ }^{2}$ In 2001 they won in each and every electoral district, obtaining all of Sicily's 61 parliamentary seats and leaving none to the centre-left coalition.
} 
press and in courts, giving rise to both judicial and anecdotal evidence. ${ }^{3}$

This evidence motivates our research question: using disaggregated data on mafia diffusion in Sicily and on vote shares at national elections between 1994 and 2013, can we find evidence of a systematic link between the Sicilian mafia and party vote shares at national political elections? If the answer is positive, can we interpret any such correlation as evidence of mafia's intervention in the market for votes?

To answer these questions, we employ party vote shares pooled across electoral years (because we look for stable connections) and we exploit information on firms and real estate properties seized to the mafia to measure its presence. Our first finding is that in mafia-plagued municipalities Berlusconi's party and coalition obtained significantly higher vote shares, whereas the centre-left coalition obtained significantly lower vote shares. Of course, while interesting, a correlation is by no means a proof of collusion. An important issue is that contemporaneous mafia measures may be endogenous, either because they are driven by omitted variables correlated with vote shares, or because they are influenced by the political activity of the different parties and hence by their vote shares.

To address endogeneity we employ two strategies. First, we use lagged rather than contemporaneous measures of mafia presence. Second, we instrument current mafia presence by its historical determinants. The first lagged measure dates back to 1987. It is taken from De Feo and De Luca (2013) and it is based on a report by the military police (Carabinieri) to a parliamentary committee (Comando Generale dell'Arma dei Carabinieri, 1987). The second lagged measure dates back to 1900 and it is based on a map of early mafia distribution elaborated by Cutrera (1900). We find that Forza Italia's vote shares are positively and significantly correlated with mafia's presence in 1987, but not in 1900, whereas votes to the centre-left are unrelated to both. Our instrumental variable strategy is based on Buonanno et al. (2015), who find that early mafia's distribution in the late XIX century was positively related to sulfur presence, difference in elevation within a municipality and agro-ecological suitability for the cultivation of cereals. Using these instruments we find that Berlusconi's party vote share is positively and significantly related to all of the above mentioned mafia measures, both contemporaneous and lagged, whereas votes for the centre-left are negatively but not significantly related to instrumented mafia presence. As Forza Italia became the new majoritarian party in Sicily, this evidence is

\footnotetext{
${ }^{3}$ In 2014 the Italian Supreme Court convicted Marcello Dell'Utri, one of Berlusconi's closest collaborators and co-founder of Forza Italia, to seven years of jail for mafia connections: between 1974 and 1992, he acted as a mediator between the Sicilian mafia and Milan business elite, including Berlusconi (Reuters, "Italy court upholds mafia conviction against Berlusconi adviser", 9 May 2014). In the 1970s Berlusconi hired a Sicilian mafioso with a known previous criminal record, Vittorio Mangano, introduced to him by Dell'Utri, to tend his horses. During Dell'Utri's trial Antonino Giuffre', a mafia boss turned investigators' informer, testified that in the same period Berlusconi paid mafia for protection, fearing the kidnapping of his son: hiring Mangano was instrumental to reduce such risk (BBC News, "Berlusconi accused of Mafia links", 8 January 2003). According to Giuffre', the Sicilian mafia supported Forza Italia since 1993, in exchange for help in resolving its judicial problems (The Guardian, "Berlusconi implicated in deal with godfathers", 5 December 2002).
} 
consistent with De Feo and De Luca (2013) theory and with the Sicilian mafia supplying votes to Berlusconi's party. At the same time, we cannot exclude that voters freely react to mafia presence by selecting a party they perceive as more suited for mafia-plagued places.

While we therefore conclude that mafia presence caused a systematic increase in Forza Italia's vote share, whether this effect was due to mafia's intervention in the market for votes, as theory as well as anecdotal and judicial evidence suggest, or to citizen's free response in the ballot box, remains unsettled.

The remainder of this paper is organized as follows. Section 2 describes the data, Section 3 presents the empirical analysis, Section 4 discusses causality, and Section 5 concludes.

\section{Data}

\subsection{Mafia Data}

We use historical and contemporary data on the presence of the mafia in Sicilian municipalities.

Our data on the early diffusion of mafia in Sicily comes from the work of Cutrera (1900), which is described in details in Buonanno et al. (2015). For each municipality, Cutrera assessed the intensity of mafia activity on a four-point scale ranging from none, to low, intermediate and high. ${ }^{4}$ For the sake of comparability with other mafia variables, we use a dummy (Mafia Cutrera) taking value one if mafia activity was present at any level (low, intermediate or high) and zero if it was absent. Cutrera's data have been extensively used in previous historical and sociological studies on the Sicilian mafia (see, e.g., Gambetta, 1993). ${ }^{5}$ The geographical distribution of the Sicilian mafia in the late XIX century, depicted in Figure 1, shows that it was more present in the Western part of the island, particularly in the areas around Palermo and Agrigento. This pattern is largely consistent with numerous reports from historians and early mafia experts (see Lupo, 1993 and Sylos Labini, 2003, among others). Descriptive statistics of this and all the other variables described in this section are collected in Table 1.

To have a more recent measure of mafia distribution, which is still predetermined with respect to our dependent variables, and therefore attenuates problems of simultaneity, we rely on data presented in De Feo and De Luca (2013), who flag Sicilian municipalities as mafia-intense if they were stronghold of main mafia families according to a 1987 military police report. This dummy variable (Mafia 1987) correlates 0.33 with the dummy based on Cutrera's data.

Finally, our measure of today's mafia presence in Sicilian municipalities exploits informa-

\footnotetext{
${ }^{4} \mathrm{~A}$ careful analysis of splits and merges of Sicilian municipalities throughout the last 120 years allows improving on Buonanno et al. (2015) and assigning Cutrera's measure to 337 rather than 285 of today's municipalities.

${ }^{5} \mathrm{An}$ alternative source of information on the early incidence of mafia activity is represented by the DamianiJacini parliamentary enquiry (Damiani, 1885).
} 
tion on firms and real estate properties seized by the Italian judicial authority to the mafia. ${ }^{6} \mathrm{We}$ define a dummy (Seizure), taking value one if by the end of 2011 at least one firm or at least one real estate property has been seized to the mafia in a given municipality (source: Agenzia del Demanio), whose distribution is depicted in Figure 2. It is worth noticing that over the considered period firms and real estate properties were seized in around $22 \%$ and $40 \%$ of Sicilian municipalities, respectively, and in more than $41 \%$ of them at least a firm or a real estate property were seized. The pairwise correlation between Seizure and the predetermined measures of mafia is 0.29 for Mafia 1987 and 0.21 for Mafia Cutrera.

By using dummy variables, we focus attention on mafia presence rather than on mafia intensity. Information on intensity is available for both contemporary and early mafia, but not for 1987. Apart from ensuring comparability across the results obtained with different measures of mafia, using dummies is one of the many steps we take to identify the causal effect of mafia on electoral outcomes: the endogeneity problem is much more severe for the number of seized firms and real estate properties than it is for the Seizure dummy. The main reason is that the number of seizures not only depends on the intensity of mafia activity, but also on public enforcement of law and on mafia lords' strategies in trials. The last two aspects are in turn likely to depend on political outcomes, and might be driven by factors that also affect electoral results. At any rate, as a robustness check we also discuss results based on mafia intensity.

\subsection{Electoral Data}

Our main dependent variable is the share of votes obtained at national political elections by Forza Italia, the party founded and led by Silvio Berlusconi since 1994. The electoral data is taken from Istituto Cattaneo's “Atlante storico-elettorale d'Italia" (Corbetta and Piretti, 2009), which collects all Italian electoral results from 1861 to 2008, and from the Interior Ministry for the elections of 2013. We use data on national elections in the period 1994-2013, specifically elections in 1994 (the first election with the new spectrum of political parties, namely the dissolution of Christian Democrats, DC, and the birth of Forza Italia), 1996, 2001, 2006, 2008 and 2013, although Forza Italia participated to the last two rounds merged with other center-right minor parties and relabeled as "Il Popolo delle Libertà" ("The People of Freedoms"). Our main dependent variable is the share of votes obtained by Forza Italia at national political elections in each municipality, averaged throughout the period (Forza Italia). Its distribution is shown in Figure 3. As an alternative dependent variable, we use the fraction of votes obtained by the aggregate of centre-left parties (Center Left). Forza Italia and Center Left add up to 0.62 on average, and their correlation is -0.8 .

Since its creation, Forza Italia obtained remarkable results in Sicily, with a 33\% share,

\footnotetext{
${ }^{6}$ Law n. 646 (September 1982), known as Law "Rognoni - La Torre" rules the seizure of firms and real estate properties belonging to mafia-type organizations.
} 
compared to the $21 \%$ share at the national level, in 1994. It gained momentum until 2001, when it got $36 \%$ share and a striking 61 out of 61 Sicilian electoral districts. After a relative drop to $30 \%$ in 2006 , it reached its peak at $47 \%$ after the merge in 2008 and its bottom at $26 \%$ in 2013, a result that preluded to the end of the new label ("Il Popolo delle Libertà") and to a return to the old name. Forza Italia has been sometimes described as the natural close substitute of Christian Democrats for electors that, after 1993, have seen their favorite party disappearing. ${ }^{7}$ However, the correlation between the share obtained by Christian Democrats in 1992 and the share obtained by Forza Italia in subsequent elections is virtually zero, as shown in the Appendix. This suggests that Forza Italia did not simply replace the Christian Democrats: it was a new political force, which in principle might have chosen to fight the mafia or to come to terms with it. Analogously, mafia families faced the choice whether to back this new party or look for alternative political alliances.

\subsection{Controls and Instruments}

In our empirical analysis we control for several variables at the municipal level. Specifically, we focus on factors that might influence both the political leaning of municipalities and the presence of mafia, in order to reduce the risk that the econometric analysis picks up spurious correlations. First we have a full set of nine provincial dummies, which take into accounts possible local political enclaves and any factor that is constant at the province level. We then have a series of municipality-level socioeconomic controls from the Italian census of 1991. This series includes population density, which ideally controls for differential voting behavior between rural and urban areas. Immigration rate is included because Forza Italia (allied in the North of Italy with the nationalistic Northern League) always proposed stricter rules for immigration, with respect to centre-left parties. We add the share of working age population with at least high school because in the Italian political tradition more educated people vote for centre-left parties. The unemployment rate is only available from the 2001 census at the level of Local Systems of Labor (which is a higher aggregation level with respect to municipalities, with around 11 municipalities on average for each Local System). Unemployment can be correlated both with mafia presence (since mafia can easily hire from the pool of unemployed people the manpower needed in the organization of extortions and other mafia-related criminal activity) and with votes for Forza Italia, whose workhorse in many rounds of elections was the creation of jobs. We also add average altitude to the set of our controls, both because it may capture differences in political interests between plain and mountain areas and, as it will become clear later, because conditioning on altitude reinforces the validity of our instruments. From the 2001 census we also have value added per capita, although at the level of Local Systems of Labor.

\footnotetext{
${ }^{7}$ After the dissolution Christian Democrats gave rise to new and smaller parties, which across elections merged and split several times, and variously joined center-right and center-left coaltions, on top of running alone.
} 
Finally, we construct a measure of tax evasion/social capital, based on the share of families that do not pay the tax for the possession of television (source: RAI).

In the second part of the empirical analysis we rely on an instrumental variable technique, as we suspect that, despite the use of dummies, each of our measures of mafia may suffer, for different reasons, from issues of either measurement error or reverse causality, and as an omitted variable bias can never be excluded with absolute certainty. In particular, for contemporary mafia measures reverse causation is a major concern, whereas for predetermined measures the main issues are measurement error and omitted variables. We use instruments that in Buonanno et al. (2015) proved to be genuinely correlated with some measures of mafia and can be safely be excluded from the second stage. In particular these instruments are the number of sulfur mines in each municipality in 1886 from Squarzina (1963), the suitability of soil for the cultivation of cereals, obtained by the FAO-GAEZ database, and the difference in altitude within a municipality, from ISTAT, the Italian statistical office. These three instruments correspond to the variables that result significant in explaining early mafia diffusion in Buonanno et al. (2015), and capture relevant aspects that, both according to their empirical analysis and to historical investigation, are related to the transformations that accompanied the rise of the Sicilian mafia in the XIX century. In particular, Buonanno et al. (2015) document how the boom in the value of sulfur resources had a significant impact on early mafia diffusion. They further show that cereal suitability proxies for the existence of large historical landholdings, another mafia predictor according to historians. Finally, difference in altitude takes into account different demand and supply factors, all in the direction of boosting the presence of mafia. Examples are the possibility for outlaws to better hide due to impervious terrain, the vulnerability of cattle during transhumance and the high cost of policing.

\section{Vote shares and mafia presence}

\subsection{Baseline analysis}

This section presents the empirical analysis of the effect of mafia presence on electoral outcomes. As discussed above, we rely on several contemporary and historical measures of mafia presence in each Sicilian municipality and we relate these measures to the share of votes obtained at national elections by Forza Italia, the party founded and led by Silvio Berlusconi since 1994. In particular, our main dependent variable is the average share of votes obtained at national elections by Forza Italia over the period 1994-2013. We pool the data across several elections for two reasons: first, this highlights systematic relationships between mafia and political parties; second, and most importantly, both contemporary and historical measures of mafia, as well as several controls presented in the previous section, are time-invariant, and this forces 
us to rely on the cross-sectional dimension. Nevertheless, we enrich our baseline estimates in order to tackle endogeneity.

Our main estimating equation is

$$
s h_{i}=8 \operatorname{mafia}_{i}+\gamma^{j} X_{i}+\varphi_{p}+\varepsilon_{i}
$$

where $s h_{i}$ is the average share of votes obtained at national elections by Forza Italia over the period 1994-2013 in municipality $i$, mafia $_{i}$ is the indicator for mafia presence as presented above, $X_{i}$ is a set of control variables, $\varphi_{p}$ are province fixed effects, and finally $\varepsilon_{i}$ is an error term. The set of observables $X_{i}$ comprises the other demographic and socioeconomic determinants of electoral outcome discussed above.

OLS estimates of equation (1) are presented in Table 2. In particular, for each measure of mafia (contemporary, predetermined and historical), we first estimate the a univariate regression of the share of votes for Forza Italia on mafia presence, and then we progressively add provincefixed effects and additional controls. Columns 1 to 3 show that contemporary mafia presence is positively and significantly correlated with the share of votes obtained by Forza Italia at national elections. This relationship is robust across alternative specifications. In terms of magnitude, contemporary mafia presence is associated with a significant increase in the share of votes obtained by Forza Italia between 4 and 6 percentage points. This means that Forza Italia obtained about $15 \%$ more votes in mafia-plagued municipalities than it did elsewhere in Sicily, a difference that was determinant in many majoritarian elections. To have an idea, in $17 \%$ of Sicilian municipalities the center-right coalition has obtained an advantage over the center-left that is lower than 6 percentage points.

Column 4 to 9 show that predetermined and historical mafia presence are also positively associated to the share of votes obtained by Forza Italia, which is 1 to 3 percentage points higher in municipalities that were plagued by mafia in 1987 (columns 4 to 6) and in the late XIX century (columns 7 to 9). Such increase in vote share is mostly significant for the predetermined but never significant for the historical measure. These results suggest that the correlation between Forza Italia's vote share and mafia presence is not an artifact of measurement problems and cannot be simply attributed to reverse causality. Yet, the use of predetermined and historical variables is not enough to eliminate concerns about endogeneity. This issue will be dealt with in more detail in Section 4.

Turning to the control variables, it emerges that immigration rate, unemployment rate, the share of individuals with high school diploma and our measure of tax evasion do not exert a significant effect on electoral outcome. Population density and GDP per capita are positively and sometimes significantly correlated with our dependent variable. 


\subsection{Robustness checks}

In this section, we perform several alternative specifications designed to test the robustness of our estimates, and we present additional results on the role of electoral systems and municipality dissolutions.

First, as a falsification test, we re-run our regressions by using as our dependent variable the share of votes obtained by the centre-left coalition, rather than the share of votes obtained by Forza Italia. Table 3 shows that contemporary mafia presence is negatively and significantly correlated to the share of votes obtained by the centre-left coalition. Such vote share was lower in mafia-plagued municipalities by 3 to 5 percentage points, but this result is not the mechanical reflection of that of Forza Italia, since their vote shares add up to 0.62 on average, so the increase in one of them does not automatically imply a reduction in the other.

Second, we investigate whether the correlations between contemporary mafia and vote shares documented so far are robust to the inclusion of finer area dummies. This is done in Table 4. Columns 1 and 2 consider Forza Italia's vote share and replicate the specification of column 3 of Table 2, substituting 77 dummies for Local Systems of Labor, and 35 dummies for electoral districts, respectively, for the 9 province dummies. The association between mafia presence and Forza Italia's vote share is confirmed in sign and significance, and only slightly reduced in magnitude (it is now between 3 and 4 percentage points). ${ }^{8}$ Columns 3 and 4 perform a similar analysis for the center-left coalition, again confirming the results in sign and significance, and with only a slight reduction in magnitude (center-left vote shares are now 2 to 3 percentage points lower in mafia-plagued municipalities). Column 5 and 6, for Forza Italia and Center Left, respectively, replicate the specification of column 3 of Table 2, substituting a continuous measure of contemporary mafia for the dummy for its presence. This new measure (Seizure rate) is the total number of mafia-related seizures per 100,000 inhabitants, and it allows to exploit information on the intensity of mafia presence. The correlation of Seizure rate with Forza Italia is positive and significant, and that with Center Left is negative and significant. Since one might wonder whether mafia presence affects only vote shares or also electoral turnout, column 7 displays a regression of voter turnout, showing that it is slightly (1 percentage point) but significantly higher in municipalities with mafia than in those without mafia.

Third, while the above analysis suggests that omitted variables and the specific measures of mafia are not driving our results, as an additional check we control for possible spatial effects. There is no reason to believe that mafia's activity follows the administrative boundaries of municipalities. Mafia bosses may indeed offer protection and practice extortion in neighboring municipalities, whose territory they control. They may also establish agreements with

\footnotetext{
${ }^{8}$ There are 42 electoral districts in Sicily, but big cities like Palermo are split in several districts, so we consider 35 dummies for electoral districts including more than one municipality. Thus, exploiting intra-district variation across municipalities means dropping information about cities.
} 
other mafia families, who control different territories. There may therefore be relevant spatial spillovers from a municipality to its neighbors. Omitting to take them into account may reduce the efficiency of our estimates and bias them.

To address this issue, we estimate a spatial model by means of the generalized spatial two stage least squares (GS2SLS) estimator of Kelejian and Prucha (1998). Results are presented in Table 5, which reproduces the most complete specification used in Table 2, using total seizures to measure contemporary mafia presence. Results for seized firms and seized real estates are analogous, but are not displayed for the sake of space. We employ both a non-standardized (columns 1 to 3 ) and a row-standardized (columns 4 to 6) contiguity matrix. We implement a spatial error model (columns 1 and 4), a spatial autoregressive model (columns 2 and 5) and a model that combines the two by considering both a spatial lag and a spatial error structure (columns 3 and 6). ${ }^{9}$

Spatial analysis is consistent with our baseline estimates. Interestingly, the autoregressive coefficients on the spatial structure are always significant, suggesting that votes for Forza Italia are spatially correlated and thus spatial estimates are justified. The main result of the spatial analysis is that, across all specifications, mafia measures are always positively and significantly related to the share of votes of Forza Italia, with a point estimated that is close to the one estimated in Table 2.

\subsection{Mafia, electoral outcomes, electoral systems, and municipality dissolution}

Table 6 presents two additional analyses, investigating whether the correlation between mafia presence and Forza Italia's vote share depends on the electoral system or changes after the dissolution of a municipality's council. The electoral system used in Italian national elections changed in 2006 from mostly majoritarian to mostly proportional. ${ }^{10}$ One may wonder which of the two systems is more permeable to mafia's influence. To this end, Column 1 presents a difference in differences exercise, in which Forza Italia's vote shares (considered as a panel) are regressed on the dummy for mafia presence (Seizure), on a dummy for post-2006 (Proportional) and on their interaction. Under the majoritarian system, Forza Italia obtained a vote share that was 5 percentage points higher in mafia-plagued municipalities than in mafia-free ones. Its

\footnotetext{
${ }^{9}$ If neighboring units have similar intercepts due to their proximity, spatial dependence appears only in the error term (LeSage and Pace, 2009) and a Spatial Error model (SEM) should be estimated. In that case, omitting the spatial specification of the error term would reduce efficiency of the estimator, while preserving consistency (Anselin, 1988). In turn, if the voting pattern in one municipality is directly affected by the voting pattern in neighboring locations, one should estimate a Spatial Autoregressive model (SAR), which includes among regressors a spatial lag, that is, a weighted average of the voting patterns in neighboring municipalities. A (non-standardized) contiguity is a proximity matrix that associates 1 to each pair of municipalities sharing a border and 0 to any other pair (the diagonal is set to 0 by convention). Row-standardization is obtained by normalizing the sum of each row of the matrix to 1 . The difference between the first and the second case is that the spatial lag captures total and average voting pattern in neighboring municipalities, respectively.

${ }^{10}$ The reform was approved by the center-right coalition, mainly with the votes of Forza Italia.
} 
vote share in Sicilian municipalities increased after 2006, with the new proportional electoral system that Forza Italia itself had chosen at the national level (possibly in view of such electoral advantage). By contrast, the interaction term is not significant, suggesting that the impact of mafia on elections is independent of the electoral system. ${ }^{11}$

Columns 2 to 5 turn to the effect of municipality dissolution. Under Law 164/1991, municipality councils can be dissolved for mafia infiltration by the Ministry of Interior. In our period of interest, around $10 \%$ of Sicilian municipalities were dissolved at some point in time. Column 2 presents the results of a panel regression of Forza Italia's vote shares on the dummy for mafia presence, a post-it dummy (Dissolution LR), where it is the year of the first dissolution of municipality $i$ (if any), and their interaction. Results show that Forza Italia obtained significantly more votes in municipalities with mafia presence and after a dissolution of the municipality council, but the interaction is not significant, implying that the effect of mafia on elections does not change before and after dissolution. Since different municipalities were dissolved in different years, Column 3 introduces time fixed effects in the regression. Under this specification, the coefficient of Seizure does not change, whereas that of Dissolution LR turns insignificant. What mostly matters here, the coefficient of the interaction is still not significant, confirming that the effect of mafia on electoral outcomes does not change after dissolution. Columns 4 and 5 (without and with time fixed effects, respectively) look at whether the effect of mafia on electoral outcomes changes at least in the election immediately following a municipality dissolution. To this end, it substitutes a corresponding dummy (Dissolution SR) for Dissolution LR, and analogously for its interaction with Seizure. The coefficient of Seizure remains virtually unaffected in both columns. Without year dummies, Dissolution $S R$ is negative and significant, whereas its interaction with Seizure is positive, significant and close in magnitude. This result suggests that, in the election immediately following a municipality dissolution, Forza Italia is punished in the ballot box where the mafia is absent, but not where it is present. Yet, both the coefficient on Dissolution $S R$ and on its interaction with Seizure turn insignificant once time fixed effects are introduced.

Taking stock of this analysis, one may draw two main conclusions. First, the coefficient of Seizure estimated in a panel analysis is extremely robust to the introduction of interaction effects with either the electoral system or the post-dissolution period. Second, the effect of mafia on electoral outcomes does not appear to depend in a robust and significant way on whether the electoral system is majoritarian or proportional, or on whether a municipality council was dissolved or not.

\footnotetext{
${ }^{11}$ Results are also robust to a sample split between the period 1994-2001 and 2006-2013, which is justified by the change in electoral rules in 2006 and by the merge of Forza Italia and Alleanza Nazionale to form the Il popolo delle liberta' in 2008. For the sake of space, these estimates are not reported, but they are available upon request.
} 


\section{Causality}

Even after controlling for other determinants of electoral outcome and for province fixed effects, mafia presence may be correlated with the error term. Indeed, estimating the effect of mafia on elections using a simple linear regression is likely to produce biased estimates for several reasons, including reverse causality, omitted variable bias and measurement error. For instance, if mafia families chose to back Forza Italia, but the latter fought the mafia more intensively than expected, reverse causality would produce an attenuation bias. By contrast, if Forza Italia's politicians actively favored mafia activities, OLS coefficients would be upward biased due to reverse causation. Omitted variables are an obvious concern, because OLS estimates might just reflect a spurious correlation, although the previous analysis reduces its relevance. Finally, it is possible that mafia's presence is mismeasured. Indeed, seized firms and real estates do not just depend on mafia activity, but also on the success of law enforcement and on judicial strategies. We tackle these problems in different ways. First, the use of predetermined mafia measures, especially those dating back to the end of the XIX century, reduces reverse causality concerns. Second, to minimize measurement errors, we rely on dummies for mafia presence, rather than exploiting more noisy information on the intensity of mafia activity. Moreover, the consistency of our results across different mafia measures reduces concerns for measurement errors. Third, we show the robustness of our results across different specifications of the set of controls. This attenuates the likelihood that we are picking up spurious correlations. Yet, ultimately, endogeneity concerns call for an instrumental variable strategy.

\subsection{IV strategy}

De Feo and De Luca (2013) instrument contemporary mafia using the measure of mafia intensity constructed by Cutrera (1900). We come close to this strategy when using Cutrera's data on mafia presence as an explanatory variable for today's vote shares, in a sort of reduced form regression. Yet, in light of mafia's persistence, one possible concern about the validity of mafia' historical distribution as an instrument for its current presence is that both might in principle be related to omitted variables that are correlated with electoral outcomes.

We look for instruments that are predictors of mafia's historical and contemporary distribution, but that are unlikely to be related to current electoral outcomes through any other channel. We follow Buonanno et al. (2015) and propose three instruments: the number of sulfur mines in each municipality in 1886 from Squarzina (1963), soil suitability for the cultivation of cereals, obtained by the FAO-GAEZ database, and difference in elevation within a municipality, from ISTAT. As discussed in Buonanno et al. (2015), these characteristics are strongly correlated with mafia's early distribution and, due to persistence, to its current distribution. At the same 
time, they capture characteristics which have very little economic and social relevance, so that they are unlikely to bear any relation to electoral outcomes through any other channel.

Sulfur became Sicily's most valuable export good in the XIX century, when the island arrived to account for more than $80 \%$ of the world's sulfur production. World demand of Sicilian sulfur increased rapidly during the Industrial Revolution, raising the demand for protection in the areas of sulfur mines. The first documented mafia-type criminal organization, the Brotherhood of Favara (Dickie, 2004), was located in the heart of the sulfur-producing area and many of its members worked in the sulfur industry at different levels. Buonanno et al. (2015) document the existence of a systematic causal link from sulfur availability to mafia's emergence (and persistence) in Sicilian municipalities. At the same time, world demand for Sicilian sulfur also rapidly declined in the XX century, due to technical change that made sulfur in other parts of the world cheaper. Today, Sicilian sulfur industry is more a memory from the past than an active sector.

Agro-ecological suitability for cereals - determined in large part by exogenous soil properties and climatic conditions - is significantly related to mafia distribution because, as noticed by several historians and recently documented by Pazzona (2010), cereals and extensive cultivations (associated with landholdings) played a relevant role in mafia's emergence. Yet the agrarian reform in 1950 significantly downplayed the role of large landholdings. At the same time, today only $8 \%$ of Sicily's cultivated land is devoted to cereal production, whose value is only a minor share of the island's GDP. Moreover, we do not measure actual production, but rather exogenous agro-ecological suitability, which is unlikely to be related to contemporary electoral outcomes through other channels.

Finally, difference in elevation, measured by the maximum difference in altitude in a given municipality, played a relevant role in the past, when it imposed significant limitations on both agriculture and cattle breeding activities (Michalopoulos, 2012; Grigg, 1995; Lupo, 1993), it raised the cost of policing and offered criminals better possibilities to hide and control the territory. While for these reasons it is significantly related to mafia distribution, it is unlikely that such aspects play a role for current electoral outcomes through other channels.

Once equipped with this set of instruments for mafia presence, we proceed to analyze the effects on electoral vote shares. Table 7 shows the results of our IV estimation that include province-fixed effects and the list of controls previously described. The first stage regression, a Linear Probability Model one, confirms that our instruments fit well. Sulfur, difference in elevation and suitability for the cultivation of cereals are often strongly significant and with the expected sign. IV diagnostic shows the relevance of the instruments. The F-test confirms that our estimations do not suffer from a weak instrument. All regression models are supported by the Hansen $\mathbf{J}$ statistic (over identification test), which does not reject the validity of our instruments. 
Overall, 2SLS estimates are qualitatively consistent with the OLS results. Nevertheless, the magnitude of our IV estimates is higher than the corresponding OLS ones. In particular, mafia presence is associated to a significant increase in the share of votes for Forza Italia between 15 and 18 percentage points (and with a reduction in the share of votes obtained by the centre-left coalition between 6 and 11 percentage points, although the latter at most marginally significant). The difference in magnitude suggests that OLS estimates are downward biased. Two possible interpretations are that such bias is due to non-random measurement errors or to reverse causality. If the data presents municipalities where the mafia is present as free of mafia, and if organized crime has a positive impact on Forza Italia's vote share, then such impact would be underestimated by OLS estimates. In turn, if mafia presence induces citizens to vote for Forza Italia, but once elected Forza Italia's members of Parliament actively fight the mafia in the municipality in which they have been elected, then again OLS estimates would underestimate the impact of mafia on electoral outcomes. Yet, this reverse causality argument can only be applied to the contemporary measure of mafia presence, whereas it does not apply to the predetermined and historical measures, for which we still find that OLS estimates are downward biased. As a consequence, reverse causality can at best only be a partial explanation, whereas the underestimation of mafia presence is potentially a problem that affects all of our measures, although we have tried to minimize it through the use of dummy variables.

\section{Conclusions}

This paper presents evidence, based on disaggregated data from the Italian region of Sicily, that between 1994 and 2013 Silvio Berlusconi's party, Forza Italia, obtained more votes at national political elections in municipalities plagued by mafia. To identify a causal relationship, it follows an instrumental variable strategy, in which mafia's presence is instrumented by three determinants of its early diffusion in the late XIX century, namely the presence of sulfur caves, difference in elevation within a municipality, and agro-ecological suitability for cereals. The results suggest that the documented correlation reflects a causal link from mafia presence to electoral outcomes. None of the results we report for Forza Italia holds if one relates the votes obtained by the centre-left coalition to mafia presence.

These findings admit two main possible interpretations. On the one hand, citizens may freely react to mafia presence by voting for a specific party, which adopts national policies that are best suited for mafia plagued environments. For instance, one might imagine that Forza Italia is either tougher against the mafia, or it is able to create more jobs, whose importance is disproportionately felt in mafia-ridden places, or it is actually milder with the mafia, and it is chosen because the short run social costs of fighting the mafia are particularly felt where organized crime is present. On the other hand, mafia lords may be able to control a certain 
share of votes, which are supplied to favorable parties. Theoretical arguments and testimonies by former mafia lords, who report that mafia families explicitly chose to back Forza Italia in exchange for more favorable policies, support the latter interpretation, although we cannot rule out the former.

By showing that historically predicted mafia presence raises a specific party's vote shares at political elections, this paper contributes to the developing literature on mafia and politics. Our evidence allows speculating on how mafia organizations secure their own persistence in a democracy, despite their negative impact on development. If mafia persistence is due to a free political majority that is tolerant towards organized crime, why does such a majority form? A possibility is that this is due to coordination problems and threshold effects. One could for instance imagine two political equilibria, one with few and one with many votes against the mafia. Fighting the mafia might be ineffective in the former and effective in the latter equilibrium, but moving from the former to the latter requires the coordinated shift on a sufficient share of votes. According to this view, Forza Italia received more votes where the mafia is present not due to vote buying, but because it was perceived as mild against the mafia, and most people expected that a tougher party would not have gained a majority, would have been ineffective against the mafia and would have consequently wasted resources. Empirically identifying this strategic element is not easy with the existing data. A complementary possibility is that mafia presence makes individuals more impatient or more myopic, and they focus on the short run costs of fighting the mafia more than on the long run benefits. If instead votes are not always freely expressed in mafia-ridden places, but are controlled by mafia lords through violence or its threat, and then sold to lenient politicians, the latter are unlikely to actively destroy one of the sources of their own power and career. Better disentangling these two perspectives remains a task for future research. 


\section{A. Appendix}

\section{A.1. Parties and coalitions}

The parties included in the coalitions are different for each election, due to the structural changing nature of Italian political system. In 1994 the center right coalition was formed by Forza Italia and Alleanza Nazionale, joined by Centro Cristiano Democratico-Centro Democratico Unito in 1996 and 2001. In 2006 the coalition was formed by Forza Italia, Alleanza Nazionale, Unione dei Democratici Cristiani e Democratici di Centro and Lega Nord. In 2008 elections Forza Italia and Alleanza Nazionale merged in Il Popolo della Libertà, which set a coalition with Movimento per l'Autonomia - Alleanza per il Sud. Such coalition was joined in 2013 elections by Fratelli d'Italia. The center left coalition was formed in 1994 by Partito Democratico della Sinistra, Partito Socialista Italiano, Rete - Movimento Democratico and Socialdemocrazia. In 1996 it included Partito Democratico della Sinistra, Popolari per Prodi, Rifondazione Comunista, Verdi and Lista Dini. In 2001 the coalition was formed by Democratici Sinistra, La Margherita and Rifondazione Comunista; in 2006 by L'Ulivo, I Socialisti and Rifondazione Comunista; in 2008 by Partito Democratico alone; and in 2013 by Partito Democratico and Sinistra, Ecologia e libertà.

\section{A.2. Votes for Christian Democrat in 1992 and Forza Italia in 1987}

Figure 4 shows that no visible correlation exists between the vote share obtained by Forza Italia in 1994 and the vote share obtained by Christian Democrats in 1987. An OLS regression of the vote share obtained by Forza Italia in 1994 on the share of Christian Democrats in 1987 delivers coherent results. Specifically, the univariate version of the regression obtains a coefficient of 0.092 with s.d. of 0.050 , while a specification including province fixed effects delivers a coefficient of 0.085 with s.d. of 0.054 .

\section{B. Aknowledgement}

An earlier version of this paper circulated as Organized Crime and Electoral Outcomes in Sicily. We are indebted to Giorgio Gulino for part of the data collection process. We thank for useful comments the editor and two anonymous referees, as well as seminar participants in Bologna, to the 2015 RIDGE/LACEA-PEG Workshop on Political Economy, and to the 2015 SIRE Workshop on the Economics of Organized Crime. We gratefully acknowledge financial support from EIEF. 


\section{References}

Acemoglu, D., J. A. Robinson, and R. J. Santos (2013). The monopoly of violence: Evidence from Colombia. Journal of the European Economic Association 11, 5-44.

Anselin, L. (1988). Spatial Econometrics: Methods and Models. Dordrecht: Kluwer Academic Publishers.

Baland, J.-M. and J. A. Robinson (2008). Land and power: Theory and evidence from Chile. American Economic Review 98(5), 1737-65.

Barone, G. and G. Narciso (2014). Organized crime and business subsidies: Where does the money go? Mimeo, Trinity College Dublin.

Buonanno, P., R. Durante, G. Prarolo, and P. Vanin (2015). Poor institutions, rich mines: Resource curse in the origins of the Sicilian mafia. Economic Journal 125(586), F175-F202.

Comando Generale dell'Arma dei Carabinieri (1987). Relazione del comandante generale dell'arma dei carabinieri alla commissione parlamentare sul fenomeno della mafia.

Corbetta, P. and M. S. Piretti (2009). Atlante storico-elettorale d?Italia (1861-2008). Bologna: Zanichelli.

Cutrera, A. (1900). La mafia e i Mafiosi. Reber, Palermo.

Damiani, A. (1885). Relazione del Commissario Abele Damiani, Deputato al Parlamento, sulla Prima Circoscrizione (Provincie di Caltanissetta, Catania, Girgenti, Messina, Palermo, Siracusa e Trapani. In S. Jacini (Ed.), Atti della Giunta per la Inchiesta Agraria e sulle Condizioni della Classe Agricola. Forzani e C., Tipografi del Senato. Anastatic reprint by Arnaldo Forni Editore in 1987.

Daniele, G. and B. Geys (2015). Organized crime, institutions and political quality: Empirical evidence from Italian municipalities. Economic Journal 125(586), F233-F255.

Daniele, V. and U. Marani (2011). Organized crime, the quality of local institutions and FDI in Italy: A panel data analysis. European Journal of Political Economy 27(1), 132-142.

De Feo, G. and G. De Luca (2013). Mafia in the ballot box. SIRE Discussion Papers 2013-104, Scottish Institute for Research in Economics (SIRE).

Dekel, E., M. O. Jackson, and A. Wolinsky (2008). Vote Buying: General Elections. Journal of Political Economy 116(2), 351-380. 
Dickie, J. (2004). Cosa Nostra. A history of the Sicilian Mafia. Palgrave Macmillan, New York.

Esteban, J. and D. Ray (2006). Inequality, lobbying, and resource allocation. American Economic Review 96(1), 257-279.

Gambetta, D. (1993). The Sicilian Mafia: the business of private protection. Harvard University Press.

Grigg, D. (1995). An introduction to agricultural geography. Routledge.

Grossman, G. M. and E. Helpman (1996). Electoral Competition and Special Interest Politics. Review of Economic Studies 63(2), 265-86.

Kelejian, H. H. and I. R. Prucha (1998). A generalized spatial two-stage least squares procedure for estimating a spatial autoregressive model with autoregressive disturbances. Journal of Real Estate Finance and Economics 17(1), 99-121.

LeSage, J. and R. K. Pace (2009). Introduction to Spatial Econometrics. London: CRC Press, Taylor \& Francis Group.

Lupo, S. (1993). Storia della mafia dalle origini ai nostri giorni. Donzelli, Roma.

Michalopoulos, S. (2012). The origins of ethnolinguistic diversity. American Economic Review 102(4), 15081539.

Pazzona, M. (2010). Emerging classes and the fight for resources: an empirical investigation into the origins of the sicilian mafia. Working paper.

Piketty, T. (1999). The information-aggregation approach to political institutions. European Economic Review 43(4-6), 791-800.

Piketty, T. (2000). Voting as Communicating. Review of Economic Studies 67(1), 169-91.

Pinotti, P. (2015). The economic cost of organized crime: Evidence from Southern Italy. Economic Journal 125(586), F203-F232.

Snyder, J. M. (1991). On buying legislatures. Economics \& Politics 3(2), 93-109.

Squarzina, F. (1963). Produzione e Commercio dello Zolfo in Sicilia nel Secolo XIX. Industria Libraria Tipografica Editrice, Torino.

Sylos Labini, P. (2003). Le radici della mafia in sicilia. In P. Sylos Labini and G. Arena (Eds.), Scritti sul mezzogiorno (1954-2001). Piero Lacaita Editore, Manduria-Bari-Roma. 


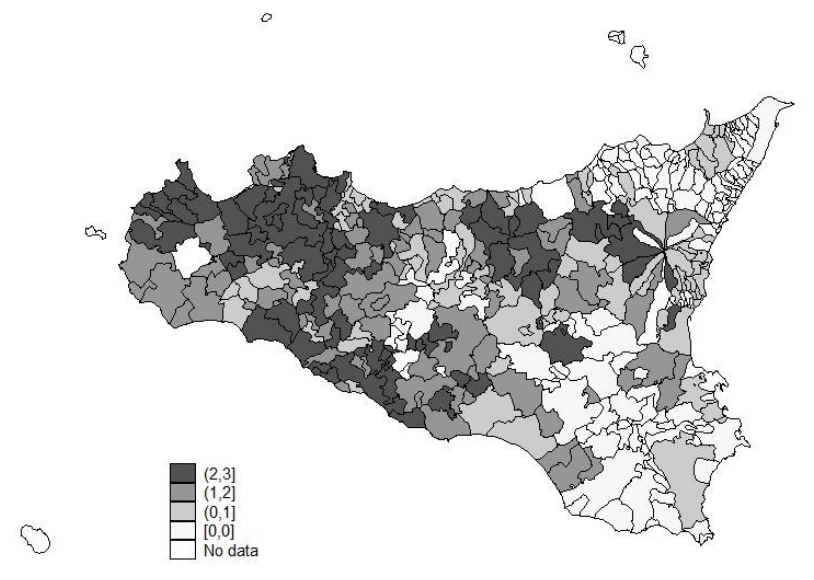

Fig. 1: Geographic Distribution of the Sicilian Mafia in the Late XIX Century

Notes. The figure reports Cutrera's (1900) assessment of the intensity of mafia activity, with darker grey indicating more mafia. Missing values (reported in white) correspond to cases for which it was not possible to match historical municipalities (or districts) to current ones, e.g. for municipalities created in the XX century. 


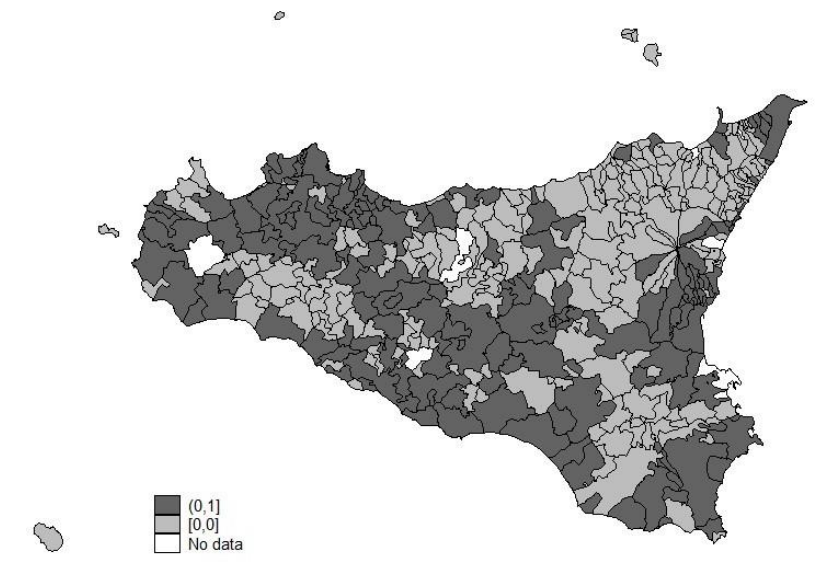

Fig. 2: Geographic Distribution of Mafia-Related Seizures in 2011

Notes. The figure shows the geographical distribution of the dummy variable indicating, for each municipality, whether by the end of 2011 at least a firm or a real estate/property were seized to the mafia by the Italian judicial authority (source: Agenzia del Demanio). 


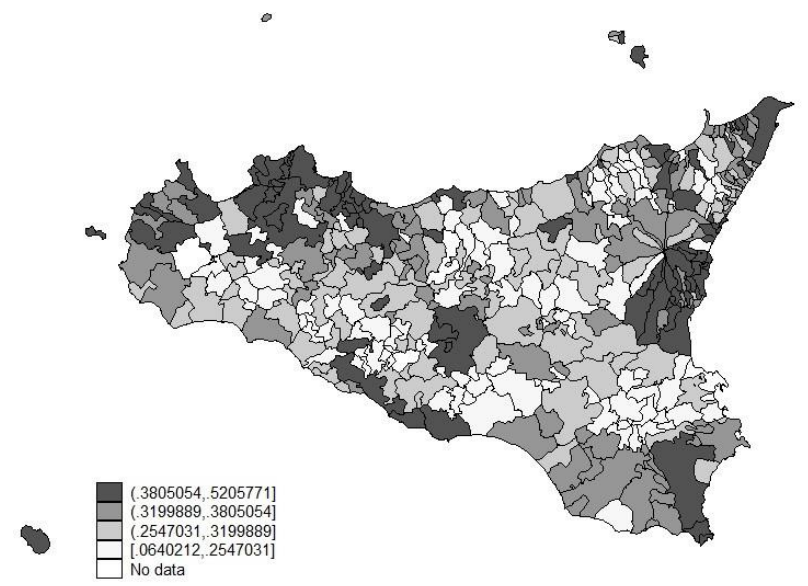

Fig. 3: Geographic Distribution of Forza Italia's Vote Share

Notes. The figure reports the distribution by municipality of the average vote share obtained by Forza Italia in elections between 1994 and 2013. 


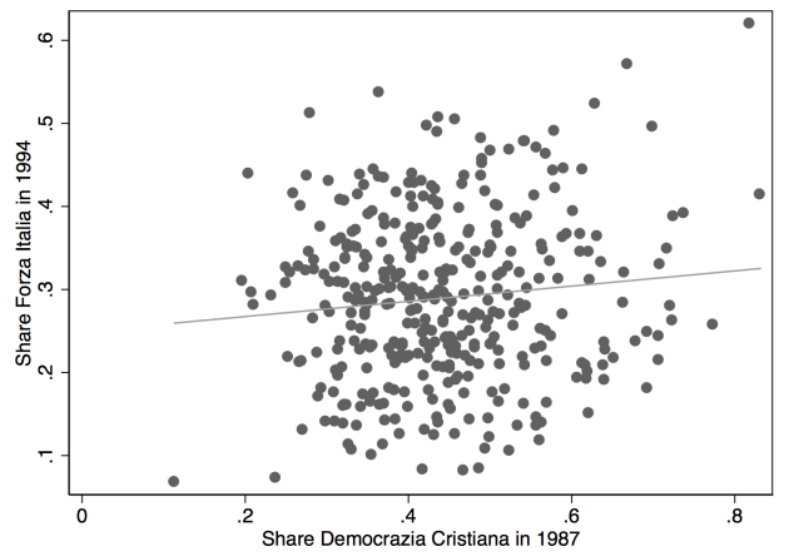

Fig. 4: Votes for Christian Democrats in 1987 and Forza Italia in 1994

Notes. The figure shows the scatterplot of the votes for Christian Democrats in 1987 and Forza Italia in 1994 for Sicilian municipalities. 
Table 1: Descriptive Statistics

\begin{tabular}{lccccc}
\hline Variable & Obs & Mean & Std. Dev. & Min & Max \\
\hline Seizure & 383 & 0.47 & 0.49 & 0 & 1 \\
Mafia 1987 & 375 & 0.22 & 0.42 & 0 & 1 \\
Mafia Cutrera & 337 & 0.70 & 0.46 & 0 & 1 \\
Forza Italia & 383 & 0.316 & 0.081 & 0.085 & 0.519 \\
Center Left & 383 & 0.301 & 0.091 & 0.084 & 0.542 \\
Turnout & 383 & 0.709 & 0.076 & 0.115 & 0.838 \\
High School & 383 & 0.123 & 0.043 & 0.012 & 0.312 \\
Immigration rate & 383 & 0.375 & 0.421 & 0 & 3.17 \\
Pop. density & 383 & 0.312 & 0.564 & 0.004 & 5.33 \\
TV fee evasion & 383 & 0.43 & 0.11 & 0 & 0.90 \\
Unemp. rate & 383 & 14.28 & 2.89 & 8.39 & 24.54 \\
GDP per capita & 383 & 11061.02 & 3653.08 & 4998.72 & 20093.51 \\
Caves & 391 & 1.32 & 5.70 & 0 & 61 \\
Difference in elevation & 390 & 774.88 & 532.84 & 40.00 & 3282.00 \\
Cereals suitability & 389 & 16.51 & 11.13 & 0 & 66.38 \\
\hline
\end{tabular}

Notes. Descriptive statistics of the main variables used in the empirical analysis. Data is at the municipality level except for GDP per capita and unemployment rate that are collected at the Local System of Labor. 
Table 2: The effect of mafia on the share of votes of Forza Italia

\begin{tabular}{|c|c|c|c|c|c|c|c|c|c|}
\hline & $(1)$ & (2) & (3) & (4) & $(5)$ & (6) & (7) & $(8)$ & (9) \\
\hline Seizure & $\begin{array}{c}0.0528 * * * \\
{[0.008]}\end{array}$ & $\begin{array}{c}0.0545 * * * \\
{[0.005]}\end{array}$ & $\begin{array}{c}0.0418 * * * \\
{[0.003]}\end{array}$ & & & & & & \\
\hline Mafia 1987 & & & & $\begin{array}{c}0.0140 \\
{[0.010]}\end{array}$ & $\begin{array}{c}0.0259 * * * \\
{[0.005]}\end{array}$ & $\begin{array}{c}0.0223 * * * \\
{[0.005]}\end{array}$ & & & \\
\hline Mafia Cutrera & & & & & & & $\begin{array}{l}0.0128 \\
{[0.009]}\end{array}$ & $\begin{array}{l}0.0177 \\
{[0.020]}\end{array}$ & $\begin{array}{l}0.0140 \\
{[0.011]}\end{array}$ \\
\hline Pop. density & & & $\begin{array}{c}0.0133^{*} \\
{[0.007]}\end{array}$ & & & $\begin{array}{c}0.0183^{*} \\
{[0.009]}\end{array}$ & & & $\begin{array}{c}0.0339 * * \\
{[0.014]}\end{array}$ \\
\hline Immigration rate & & & $\begin{array}{l}0.0025 \\
{[0.009]}\end{array}$ & & & $\begin{array}{l}0.0034 \\
{[0.008]}\end{array}$ & & & $\begin{array}{l}0.0008 \\
{[0.006]}\end{array}$ \\
\hline High school & & & $\begin{array}{c}-0.0236 \\
{[0.099]}\end{array}$ & & & $\begin{array}{l}0.0658 \\
{[0.104]}\end{array}$ & & & $\begin{array}{l}0.1052 \\
{[0.092]}\end{array}$ \\
\hline TV fee evasion & & & $\begin{array}{l}5.9242 \\
{[7.236]}\end{array}$ & & & $\begin{array}{c}6.8469 \\
{[8.871]}\end{array}$ & & & $\begin{array}{l}6.2180 \\
{[7.475]}\end{array}$ \\
\hline Unemp. rate & & & $\begin{array}{c}0.0759 \\
{[0.254]}\end{array}$ & & & $\begin{array}{c}0.1166 \\
{[0.286]}\end{array}$ & & & $\begin{array}{c}0.1462 \\
{[0.283]}\end{array}$ \\
\hline GPD per capita & & & $\begin{array}{l}0.0017 \\
{[0.001]}\end{array}$ & & & $\begin{array}{c}0.0021 \\
{[0.001]}\end{array}$ & & & $\begin{array}{c}0.0012 \\
{[0.001]}\end{array}$ \\
\hline Average altitude & & & $\begin{array}{l}-0.0313 \\
{[0.032]}\end{array}$ & & & $\begin{array}{l}-0.0333 \\
{[0.035]}\end{array}$ & & & $\begin{array}{l}-0.0241 \\
{[0.037]}\end{array}$ \\
\hline Prov. FE & $\mathrm{N}$ & Y & $\mathrm{Y}$ & $\mathrm{N}$ & $\mathrm{Y}$ & Y & $\mathrm{N}$ & Y & $\mathrm{Y}$ \\
\hline Observations & 383 & 383 & 382 & 375 & 375 & 374 & 337 & 337 & 336 \\
\hline R-squared & 0.105 & 0.242 & 0.288 & 0.005 & 0.168 & 0.256 & 0.005 & 0.171 & 0.267 \\
\hline
\end{tabular}

Notes. This table presents the main results of OLS estimates. The dependent variable is the average share of votes obtained at national elections by Forza Italia over the period 1994-2013. The explanatory variable in columns 1 to 3 is a dummy indicating whether by 2011 at least one firm or at least one real estate property were seized to the mafia in a given municipality (source: Agenzia del Demanio). In columns 4 to 6 the explanatory variable is a dummy variable indicating whether mafia was active according to a 1987 military police report to a parliamentary committee (Comando Generale dell'Arma dei Carabinieri, 1987). Finally, in columns 7 to 9 the explanatory variable is a dummy variable indicating whether mafia was active according to Cutrera (1900), while the other control variables are described in the main text. Robust standard errors (clustered at the province level when province dummies are introduced) are presented in parentheses. $*, * *$ and $* * *$ denote rejection of the null hypothesis of the coefficient being equal to 0 at $10 \%, 5 \%$ and $1 \%$ significance level, respectively. 
Table 3: The effect of mafia on the share of votes of the centre-left coalition

\begin{tabular}{|c|c|c|c|c|c|c|c|c|c|}
\hline & $(1)$ & $(2)$ & (3) & (4) & $(5)$ & (6) & (7) & $(8)$ & (9) \\
\hline Seizure & $\begin{array}{c}-0.0380^{* * * *} \\
{[0.008]}\end{array}$ & $\begin{array}{c}-0.0460 * * * * \\
{[0.006]}\end{array}$ & $\begin{array}{c}-0.0347 * * * \\
{[0.006]}\end{array}$ & & & & & & \\
\hline Mafia 1987 & & & & $\begin{array}{l}0.0037 \\
{[0.010]}\end{array}$ & $\begin{array}{l}-0.0102 \\
{[0.009]}\end{array}$ & $\begin{array}{l}-0.0078 \\
{[0.008]}\end{array}$ & & & \\
\hline Mafia Cutrera & & & & & & & $\begin{array}{l}0.0105 \\
{[0.010]}\end{array}$ & $\begin{array}{l}0.0007 \\
{[0.026]}\end{array}$ & $\begin{array}{c}0.0042 \\
{[0.017]}\end{array}$ \\
\hline Pop. density & & & $\begin{array}{l}-0.0069 \\
{[0.005]}\end{array}$ & & & $\begin{array}{l}-0.0104 \\
{[0.006]}\end{array}$ & & & $\begin{array}{c}-0.0218^{*} \\
{[0.011]}\end{array}$ \\
\hline Immigration rate & & & $\begin{array}{l}-0.0038 \\
{[0.008]}\end{array}$ & & & $\begin{array}{l}-0.0041 \\
{[0.007]}\end{array}$ & & & $\begin{array}{l}-0.0001 \\
{[0.004]}\end{array}$ \\
\hline High school & & & $\begin{array}{l}0.0615 \\
{[0.152]}\end{array}$ & & & $\begin{array}{l}-0.0133 \\
{[0.149]}\end{array}$ & & & $\begin{array}{l}-0.0151 \\
{[0.140]}\end{array}$ \\
\hline TV fee evasion & & & $\begin{array}{c}-13.5289 * * * \\
{[3.966]}\end{array}$ & & & $\begin{array}{c}-14.7906 * * * \\
{[4.113]}\end{array}$ & & & $\begin{array}{c}-13.6943^{* * *} * \\
{[3.213]}\end{array}$ \\
\hline Unemp. rate & & & $\begin{array}{l}0.0238 \\
{[0.313]}\end{array}$ & & & $\begin{array}{r}-0.0347 \\
{[0.344]}\end{array}$ & & & $\begin{array}{l}-0.0745 \\
{[0.329]}\end{array}$ \\
\hline GPD per capita & & & $\begin{array}{l}-0.0023 \\
{[0.002]}\end{array}$ & & & $\begin{array}{c}-0.0028^{*} \\
{[0.001]}\end{array}$ & & & $\begin{array}{l}-0.0018 \\
{[0.001]}\end{array}$ \\
\hline Average altitude & & & $\begin{array}{l}0.0214 \\
{[0.019]}\end{array}$ & & & $\begin{array}{l}0.0241 \\
{[0.024]}\end{array}$ & & & $\begin{array}{l}0.0167 \\
{[0.027]}\end{array}$ \\
\hline Prov. FE & $\mathrm{N}$ & $\mathrm{Y}$ & Y & $\mathrm{N}$ & $\mathrm{Y}$ & $\mathrm{Y}$ & $\mathrm{N}$ & $\mathrm{Y}$ & $\mathrm{Y}$ \\
\hline Observations & 383 & 383 & 382 & 375 & 375 & 374 & 337 & 337 & 336 \\
\hline R-squared & 0.051 & 0.219 & 0.269 & 0.000 & 0.159 & 0.239 & 0.003 & 0.176 & 0.250 \\
\hline
\end{tabular}

Notes. This table presents the results of OLS estimates. The dependent variable is the average share of votes obtained at national elections by the centre-left coalition over the period 1994-2013. The explanatory variable in columns 1 to 3 is a dummy indicating whether by 2011 at least one firm or at least one real estate property were seized to the mafia in a given municipality (source: Agenzia del Demanio). In columns 4 to 6 the explanatory variable is a dummy variable indicating whether mafia was active according to a 1987 military police report to a parliamentary committee (Comando Generale dell'Arma dei Carabinieri, 1987). Finally, in columns 7 to 9 the explanatory variable is a dummy variable indicating whether mafia was active according to Cutrera (1900), while the other control variables are described in the main text. Robust standard errors (clustered at the province level when province dummies are introduced) are presented in parentheses. *, ** and *** denote rejection of the null hypothesis of the coefficient being equal to 0 at $10 \%, 5 \%$ and $1 \%$ significance level, respectively. 
Table 4: Additional estimates: area dummies, continuous mafia mesures, and turnout

\begin{tabular}{|c|c|c|c|c|c|c|c|}
\hline VARIABLES & $\begin{array}{c}(1) \\
\text { Forza Italia }\end{array}$ & $\begin{array}{c}(2) \\
\text { Forza Italia } \\
\end{array}$ & $\begin{array}{c}3) \\
\text { Center Left }\end{array}$ & $\begin{array}{c}(4) \\
\text { Center Left }\end{array}$ & $\begin{array}{c}5) \\
\text { Forza Italia }\end{array}$ & $\begin{array}{c}(6) \\
\text { Center Left }\end{array}$ & $\begin{array}{c}\text { (7) } \\
\text { Turnout }\end{array}$ \\
\hline Seizure & $\begin{array}{c}0.0319 * * * \\
{[0.010]}\end{array}$ & $\begin{array}{c}0.0368 * * * \\
{[0.007]}\end{array}$ & $\begin{array}{c}-0.0237 * * \\
{[0.009]}\end{array}$ & $\begin{array}{c}-0.0313 * * * \\
{[0.007]}\end{array}$ & & & $\begin{array}{c}0.0138 * \\
{[0.007]}\end{array}$ \\
\hline Seizure rate & & & & & $\begin{array}{c}0.0002 * * \\
{[0.000]}\end{array}$ & $\begin{array}{c}-0.0001 * \\
{[0.000]}\end{array}$ & \\
\hline Pop. density & $\begin{array}{c}0.0032 \\
{[0.008]}\end{array}$ & $\begin{array}{l}0.0063 \\
{[0.011]}\end{array}$ & $\begin{array}{c}0.0009 \\
{[0.006]}\end{array}$ & $\begin{array}{c}0.0046 \\
{[0.007]}\end{array}$ & $\begin{array}{c}0.0166^{*} \\
{[0.007]}\end{array}$ & $\begin{array}{c}-0.0096^{*} \\
{[0.005]}\end{array}$ & $\begin{array}{c}0.0031 \\
{[0.007]}\end{array}$ \\
\hline Immigration rate & $\begin{array}{l}0.0051 \\
{[0.009]}\end{array}$ & $\begin{array}{c}0.0181 * \\
{[0.010]}\end{array}$ & $\begin{array}{l}-0.0041 \\
{[0.008]}\end{array}$ & $\begin{array}{c}-0.0204 * * \\
{[0.010]}\end{array}$ & $\begin{array}{c}-0.0028 \\
{[0.011]}\end{array}$ & $\begin{array}{c}0.0003 \\
{[0.010]}\end{array}$ & $\begin{array}{c}-0.0307 * * * \\
{[0.007]}\end{array}$ \\
\hline High school & $\begin{array}{l}-0.0303 \\
{[0.110]}\end{array}$ & $\begin{array}{l}-0.0973 \\
{[0.103]}\end{array}$ & $\begin{array}{c}0.1508 \\
{[0.109]}\end{array}$ & $\begin{array}{c}0.1994 * \\
{[0.116]}\end{array}$ & $\begin{array}{c}0.0884 \\
{[0.092]}\end{array}$ & $\begin{array}{c}-0.0301 \\
{[0.141]}\end{array}$ & $\begin{array}{c}0.5134 * * * \\
{[0.107]}\end{array}$ \\
\hline TV fee evasion & $\begin{array}{l}2.5872 \\
{[7.625]}\end{array}$ & $\begin{array}{l}1.5702 \\
{[5.870]}\end{array}$ & $\begin{array}{c}-10.4589 \\
{[6.375]}\end{array}$ & $\begin{array}{l}-7.9680 \\
{[5.105]}\end{array}$ & $\begin{array}{l}7.1893 \\
{[8.785]}\end{array}$ & $\begin{array}{c}-14.6063 * * \\
{[4.580]}\end{array}$ & $\begin{array}{l}0.7115 \\
{[5.381]}\end{array}$ \\
\hline Unemp. rate & & $\begin{array}{l}-0.2486 \\
{[0.234]}\end{array}$ & & $\begin{array}{c}0.3525 \\
{[0.236]}\end{array}$ & $\begin{array}{c}0.1538 \\
{[0.277]}\end{array}$ & $\begin{array}{l}-0.0398 \\
{[0.333]}\end{array}$ & $\begin{array}{c}-0.2859 \\
{[0.225]}\end{array}$ \\
\hline GDP per capita & & $\begin{array}{l}0.0008 \\
{[0.001]}\end{array}$ & & $\begin{array}{l}-0.0018 \\
{[0.001]}\end{array}$ & $\begin{array}{l}0.0023 \\
{[0.001]}\end{array}$ & $\begin{array}{l}-0.0028 \\
{[0.002]}\end{array}$ & $\begin{array}{c}-0.0006 \\
{[0.002]}\end{array}$ \\
\hline Average altitude & $\begin{array}{c}-0.0348 * \\
{[0.019]}\end{array}$ & $\begin{array}{c}-0.0628 * * * \\
{[0.017]}\end{array}$ & $\begin{array}{l}0.0269 \\
{[0.017]}\end{array}$ & $\begin{array}{c}0.0533 * * * \\
{[0.015]}\end{array}$ & $\begin{array}{l}-0.0334 \\
{[0.035]}\end{array}$ & $\begin{array}{c}0.0232 \\
{[0.022]}\end{array}$ & $\begin{array}{c}-0.0044 \\
{[0.008]}\end{array}$ \\
\hline FE & LSL & ED & LSL & ED & Prov & Prov & Prov \\
\hline Observations & 382 & 382 & 382 & 382 & 382 & 382 & 382 \\
\hline R-squared & 0.537 & 0.450 & 0.537 & 0.376 & 0.249 & 0.243 & 0.267 \\
\hline
\end{tabular}

Notes. This table presents the results of further OLS estimates. The dependent variable is (i) the average share of votes obtained at national elections by Forza Italia in the period 1994-2013 (columns 1, 2 and 5), (ii) the average share of votes obtained at national elections by the center-left coalition in the period 1994-2013 (columns 3, 4 and 6) and (iii) the average turnout at national elections in the period 1994-2013 (column 7). The explanatory variable is a dummy indicating whether by 2011 at least one firm or at least one real estate property were seized to the mafia in a given municipality (source: Agenzia del Demanio), except for columns 5 and 6 where it is the total number of firm and real estate seized to the mafia in a given municipality per 100,000 inhabitants. The control variables are described in the main text, while fixed effects (and the clustering of standard errors) are at the level of 77 Local Systems of Labor (column 1 and 3), 35 electoral districts (columns 2 and 4 ) and 10 provinces (columns 5 to 7). Robust standard errors clustered at the relevant geographical level are presented in parentheses. $* * *$ and $* * *$ denote rejection of the null hypothesis of the coefficient being equal to 0 at $10 \%, 5 \%$ and $1 \%$ significance level, respectively. 
Table 5: Spatial estimates: share of votes for Forza Italia

\begin{tabular}{|c|c|c|c|c|c|c|}
\hline & $(1)$ & (2) & (3) & (4) & $(5)$ & (6) \\
\hline Seizure & $\begin{array}{c}0.0438 * * * \\
{[0.008]}\end{array}$ & $\begin{array}{c}0.0340 * * * \\
{[0.008]}\end{array}$ & $\begin{array}{c}0.0337 * * * \\
{[0.008]}\end{array}$ & $\begin{array}{c}0.0447 * * * \\
{[0.009]}\end{array}$ & $\begin{array}{c}0.0315^{* * *} \\
{[0.008]}\end{array}$ & $\begin{array}{c}0.0315^{* * * *} \\
{[0.008]}\end{array}$ \\
\hline Pop. density & $\begin{array}{c}0.0156^{*} \\
{[0.008]}\end{array}$ & $\begin{array}{c}0.0139 \\
{[0.009]}\end{array}$ & $\begin{array}{c}0.0142^{*} \\
{[0.009]}\end{array}$ & $\begin{array}{c}0.0161 * \\
{[0.009]}\end{array}$ & $\begin{array}{c}0.0147 * \\
{[0.009]}\end{array}$ & $\begin{array}{c}0.0157^{*} \\
{[0.009]}\end{array}$ \\
\hline Immgration rate & $\begin{array}{l}0.0008 \\
{[0.010]}\end{array}$ & $\begin{array}{l}0.0012 \\
{[0.009]}\end{array}$ & $\begin{array}{l}0.0014 \\
{[0.009]}\end{array}$ & $\begin{array}{l}0.0005 \\
{[0.010]}\end{array}$ & $\begin{array}{l}0.0030 \\
{[0.009]}\end{array}$ & $\begin{array}{c}0.0028 \\
{[0.009]}\end{array}$ \\
\hline High school & $\begin{array}{l}0.0195 \\
{[0.107]}\end{array}$ & $\begin{array}{l}0.0057 \\
{[0.102]}\end{array}$ & $\begin{array}{c}-0.0014 \\
{[0.102]}\end{array}$ & $\begin{array}{c}0.0183 \\
{[0.107]}\end{array}$ & $\begin{array}{l}-0.0021 \\
{[0.101]}\end{array}$ & $\begin{array}{l}-0.0103 \\
{[0.100]}\end{array}$ \\
\hline TV fee evasion & $\begin{array}{l}4.4610 \\
{[3.922]}\end{array}$ & $\begin{array}{l}5.5714 \\
{[3.863]}\end{array}$ & $\begin{array}{l}5.3997 \\
{[3.863]}\end{array}$ & $\begin{array}{l}4.9336 \\
{[3.959]}\end{array}$ & $\begin{array}{l}5.2083 \\
{[3.923]}\end{array}$ & $\begin{array}{l}5.8546 \\
{[3.931]}\end{array}$ \\
\hline Unemp. rate & $\begin{array}{c}0.1148 \\
{[0.198]}\end{array}$ & $\begin{array}{l}-0.0163 \\
{[0.215]}\end{array}$ & $\begin{array}{l}-0.0371 \\
{[0.214]}\end{array}$ & $\begin{array}{c}0.1284 \\
{[0.199]}\end{array}$ & $\begin{array}{c}0.0309 \\
{[0.222]}\end{array}$ & $\begin{array}{c}0.0352 \\
{[0.222]}\end{array}$ \\
\hline GDP per capita & $\begin{array}{c}0.0020^{*} \\
{[0.001]}\end{array}$ & $\begin{array}{c}0.0023^{*} \\
{[0.001]}\end{array}$ & $\begin{array}{c}0.0022^{*} \\
{[0.001]}\end{array}$ & $\begin{array}{l}0.0021 * \\
{[0.001]}\end{array}$ & $\begin{array}{c}0.0025 * * \\
{[0.001]}\end{array}$ & $\begin{array}{c}0.0024 * * \\
{[0.001]}\end{array}$ \\
\hline Average altitude & $\begin{array}{c}-0.0339 * * \\
{[0.014]}\end{array}$ & $\begin{array}{c}-0.0514 * * * \\
{[0.016]}\end{array}$ & $\begin{array}{c}-0.0527 * * * \\
{[0.016]}\end{array}$ & $\begin{array}{c}-0.0307 * * \\
{[0.013]}\end{array}$ & $\begin{array}{c}-0.0360^{* *} \\
{[0.015]}\end{array}$ & $\begin{array}{c}-0.0363^{* *} \\
{[0.015]}\end{array}$ \\
\hline$\lambda$ & $\begin{array}{c}0.0030 \\
{[0.004]}\end{array}$ & & $\begin{array}{c}0.0029 \\
{[0.005]}\end{array}$ & $\begin{array}{l}-0.0195 \\
{[0.038]}\end{array}$ & & $\begin{array}{c}-0.0484 \\
{[0.040]}\end{array}$ \\
\hline$\rho$ & & $\begin{array}{c}0.0858 * * * \\
{[0.011]}\end{array}$ & $\begin{array}{c}0.0848^{* * * *} \\
{[0.011]}\end{array}$ & & $\begin{array}{c}0.4286 * * * \\
{[0.062]}\end{array}$ & $\begin{array}{c}0.4646 * * * \\
{[0.066]}\end{array}$ \\
\hline Observations & 382 & 382 & 382 & 382 & 382 & 382 \\
\hline
\end{tabular}

Notes. This table presents the results of a spatial model estimated by means of the generalised spatial two stage least squares (GS2SLS) estimator of Kelejian and Prucha (1998), with the most complete specification used in Table 2. The explanatory variable is a dummy indicating whether by 2011 at least one firm or at least one real estate property were seized to the mafia in a given municipality (source: Agenzia del Demanio). Columns 1 to 3 employ a non-standardised contiguity matrix, while a row-standardised one is used in columns 4 to 6 . A Spatial Error model, a Spatial Autoregressive model and a model that combines the two by considering both a spatial lag and a spatial error structure are respectively presented in columns 1 and 4, columns 2 and 5 and columns 3 and $6 . \lambda$ is the spatial error term, while $\rho$ is the spatial lag. The dependent variable is the average share of votes obtained at national elections by Forza Italia over the period 1994-2013. Robust standard errors (clustered at the province level when province dummies are introduced) are presented in parentheses. *, ** and *** denote rejection of the null hypothesis of the coefficient being equal to 0 at $10 \%, 5 \%$ and $1 \%$ significance level, respectively. 
Table 6: DID estimates: mafia on share of votes of Forza Italia

\begin{tabular}{|c|c|c|c|c|c|}
\hline & $(1)$ & $(2)$ & (3) & (4) & $(5)$ \\
\hline Seizure & $\begin{array}{c}0.0529 * * * \\
{[0.008]}\end{array}$ & $\begin{array}{c}0.0469 * * * \\
{[0.008]}\end{array}$ & $\begin{array}{c}0.0511 * * * \\
{[0.008]}\end{array}$ & $\begin{array}{c}0.0533 * * * \\
{[0.008]}\end{array}$ & $\begin{array}{c}0.0524 * * * \\
{[0.008]}\end{array}$ \\
\hline Proportional & $\begin{array}{c}0.0517 * * * \\
{[0.004]}\end{array}$ & & & & \\
\hline Seizure*Proportional & $\begin{array}{c}-0.0003 \\
{[0.005]}\end{array}$ & & & & \\
\hline Dissolution LR & & $\begin{array}{c}0.0332 * * \\
{[0.016]}\end{array}$ & $\begin{array}{l}-0.0042 \\
{[0.017]}\end{array}$ & & \\
\hline Seizure*dissolution LR & & $\begin{array}{c}0.0091 \\
{[0.019]}\end{array}$ & $\begin{array}{l}0.0152 \\
{[0.019]}\end{array}$ & & \\
\hline Dissolution SR & & & & $\begin{array}{c}-0.0377 * * * \\
{[0.006]}\end{array}$ & $\begin{array}{l}-0.0064 \\
{[0.010]}\end{array}$ \\
\hline Seizure*dissolution SR & & & & $\begin{array}{c}0.0253 * * * \\
{[0.009]}\end{array}$ & $\begin{array}{c}0.0138 \\
{[0.011]}\end{array}$ \\
\hline Year FE & No & No & Yes & No & Yes \\
\hline Observations & 2,298 & 2,298 & 2,298 & 2,298 & 2,298 \\
\hline Number of municipalities & 383 & 383 & 383 & 383 & 383 \\
\hline
\end{tabular}

Notes. This table presents the results of differences-in-differences estimates. The dependent variable is the share of votes obtained at national elections by Forza Italia in each election from 1994 to 2013. The explanatory variables in column 1 are the time invariant dummy indicating whether by 2011 at least one firm or at least one real estate property were seized to the mafia in a given municipality (source: Agenzia del Demanio), a dummy for post-2006 representing the adoption of the proportional electoral system and their interaction. The explanatory variables in columns 2 and 3 (4 and 5) are the time invariant dummy indicating whether by 2011 at least one firm or at least one real estate property were seized to the mafia in a given municipality (source: Agenzia del Demanio), a dummy taking value one from the year (only the year) in which the municipality has been dissolved, and their interaction. Province fixed effects are included in columns 3 and 5 . Robust standard errors clustered at the province level are presented in parentheses. *, ** and *** denote rejection of the null hypothesis of the coefficient being equal to 0 at $10 \%, 5 \%$ and $1 \%$ significance level, respectively. 
Table 7: IV estimates: mafia on share of votes of Forza Italia and centre-left coalition

\begin{tabular}{|c|c|c|c|c|c|c|}
\hline & \multicolumn{6}{|c|}{ PANEL A: First stage } \\
\hline & (1) & (2) & (3) & (4) & (5) & (6) \\
\hline \multirow[t]{2}{*}{ Caves } & $0.0069 * *$ & $0.0076^{*}$ & 0.0036 & $0.0069 * *$ & $0.0076^{*}$ & 0.0036 \\
\hline & {$[0.003]$} & {$[0.004]$} & {$[0.002]$} & {$[0.003]$} & {$[0.004]$} & {$[0.002]$} \\
\hline \multirow[t]{2}{*}{ Difference in elevation } & $0.2248 * * *$ & 0.0511 & $0.1532 *$ & $0.2248 * * *$ & 0.0511 & $0.1532 *$ \\
\hline & {$[0.087]$} & {$[0.066]$} & {$[0.087]$} & {$[0.087]$} & [0.066] & [0.087] \\
\hline \multirow[t]{2}{*}{ Cereals suitability } & 0.0051 & 0.0022 & $0.0086^{* * *}$ & 0.0051 & 0.0022 & $0.0086^{* * *}$ \\
\hline & {$[0.003]$} & {$[0.003]$} & {$[0.002]$} & {$[0.003]$} & [0.003] & {$[0.002]$} \\
\hline F-test & 13.123 & 4.046 & 15.625 & 13.123 & 4.046 & 15.625 \\
\hline \multirow[t]{5}{*}{ Hansen $\mathbf{J}$ statistics } & 2.916 & 9.995 & 1.642 & 2.916 & 9.995 & 1.642 \\
\hline & {$[0.2327]$} & {$[0.0068]$} & {$[0.4401]$} & {$[0.4928]$} & {$[0.2300]$} & {$[0.6128]$} \\
\hline & \multicolumn{6}{|c|}{ PANEL B: Second stage } \\
\hline & $(1)$ & $(2)$ & (3) & (4) & $(5)$ & (6) \\
\hline & Forza Italia & Forza Italia & Forza Italia & Center Left & Center Left & Center Left \\
\hline Seizure & $\begin{array}{c}0.1655^{* * * *} \\
{[0.0570]}\end{array}$ & & & $\begin{array}{c}-0.0859 * \\
{[0.044]}\end{array}$ & & \\
\hline \multirow[t]{2}{*}{ Mafia 1987} & & $0.1819 * * *$ & & & -0.1104 & \\
\hline & & {$[0.083]$} & & & {$[0.070]$} & \\
\hline \multirow[t]{2}{*}{ Mafia Cutrera } & & & $0.1537 * * *$ & & & -0.0608 \\
\hline & & & [0.058] & & & [0.049] \\
\hline Observations & 381 & 373 & 335 & 381 & 373 & 335 \\
\hline
\end{tabular}

Notes. This table presents the results of the IV estimates. Panel A reports the first stage, while panel B reports the second stage. The dependent variable is the average share of votes obtained at national elections by Forza Italia over the period 1994-2013 (columns 1 to 3) and the average share of votes obtained at national elections by the center-left coalition over the period 1994-2013 (columns 4 to 6 ). The instrumented explanatory variable in columns 1 and 4 is a dummy indicating whether by 2011 at least one firm or at least one real estate property were seized to the mafia in a given municipality (source: Agenzia del Demanio). In columns 2 and 5 the instrumented explanatory variables is a dummies indicating whether mafia was active according to a 1987 military police report to a parliamentary committee (Comando Generale dell'Arma dei Carabinieri, 1987). In columns 3 and 6 the instrumented explanatory variable is a dummies indicating whether mafia was active according to Cutrera (1900). The other control variables are described in the main text. Province fixed effects are always included. Robust standard errors clustered at the province level are presented in parentheses. *, ** and $* * *$ denote rejection of the null hypothesis of the coefficient being equal to 0 at $10 \%, 5 \%$ and $1 \%$ significance level, respectively. 